\title{
GEOCHEMISTRY AND TECTONIC SETTING OF ECLOGITE PROTOLITHS FROM KECHROS COMPLEX IN EAST RHODOPE (N.E. GREECE)
}

\author{
Baziotis I. and Mposkos E. \\ National Technical University of Athens, Department of Mining and Metallurgical Engineering, Section of \\ Geological Sciences, Heroon Polytechniou 9, 15780,Athens, Greece,mposkos@metal.ntua.gr, \\ baziotis@metal.ntua.gr
}

\begin{abstract}
Eclogites and partially amphibolitized eclogites from the metamorphic Kechros complex in East Rhodope are studied in order to provide the geodynamic framework for the origin of their protoliths. Geochemical evidence from whole-rock major and trace element concentrations shows two distinct protolith groups. The low-Fe-Ti eclogites (Charakoma locality) have low-TiO $\mathrm{O}_{2}$ content $(<0.67 \mathrm{wt} \%)$, negative $\mathrm{Nb}$ anomalies, positive $\mathrm{Sr}$ anomalies, small negative $\mathrm{Zr}$ and $\mathrm{Hf}$ anomalies and variable enrichments in LILE (e.g. Rb and $\mathrm{Ba}$ ). The REE patterns are characterized by strong LREE enrichment $\left(L a_{N} / Y b_{N}=5.45-5.81\right)$, HREE depletion $\left(G d_{N} / Y b_{N}=1.60-1.63\right)$ and HREE abundance within the range of $9-10 \times$ chondrite. The high-Fe-Ti eclogites (Kovalo and Virsini locality) have variable Sr contents, small to moderate LILE enrichment, HREE's similar to MORB values and absence of Nb anomalies. The REE patterns of the Kovalo and Virsini eclogites are characterized by LREE depletion and relative flat MREE-HREE patterns at approximately 20-30 x chondrite concentrations. Our results suggest that the protoliths of the Low-Ti eclogites show a continental rifting tectonic environment. In contrast, the protoliths of the High-Ti eclogites indicate formation of their protoliths by partial melting in an extensional oceanic environment.
\end{abstract}

Key words: eclogites, amphibolitized eclogites, Kechros Complex, Rhodope.

\section{Introduction}

Eclogites are high-pressure rocks that consist of omphacite and garnet, have broadly basaltic to intermediate composition and occur in a variety of geotectonic environments. Geochemical investigations are of great importance to elucidate the geotectonic environment of their protoliths and to provide important information on the tectonic evolution of the orogenic belts (e.g. Ernst and Liou, 1995).

The Rhodope high-pressure (HP) Province represents an Alpine synmetamorphic thrust and nappe complex that incorporates several tectonic slivers of ultra-high pressure (UHP) and HP metamorphic rocks formed during the Jurassic to Mid-Tertiary collision of the African and European plates (Burg et al., 1996; Liati and Mposkos, 1990; Mposkos and Krohe, 2000). It offers a great opportunity to study the geochemistry of such HP rocks, since they are common in the most tectonometamorphic complexes of it (Mposkos and Krohe, 2000). In the eastern Rhodope, the structurally uppermost Kimi Complex underwent UHP-HT metamorphism in early Jurassic (Mposkos and Kostopoulos, 2001; Bauer et al., 2007) and exhumed to the surface between 62 and $48 \mathrm{Ma}$ (Krohe and Mposkos, 


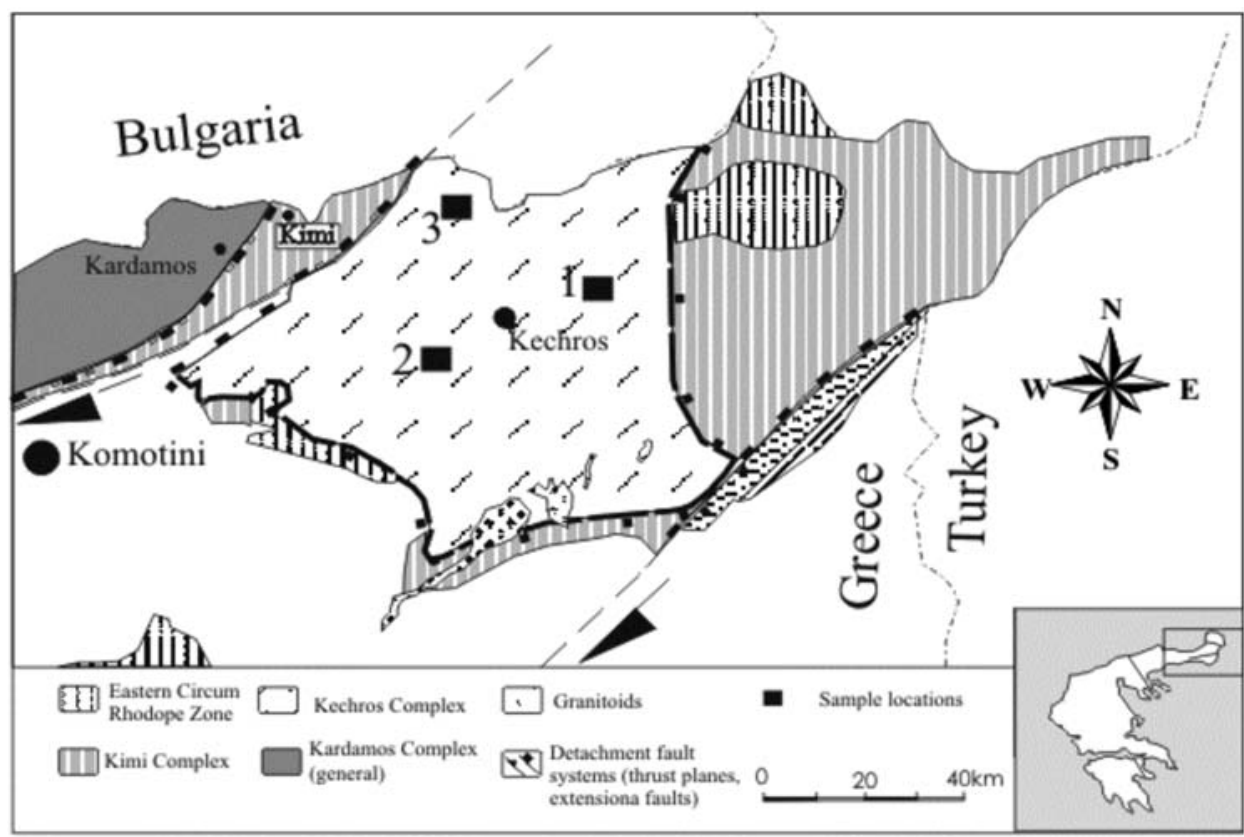

Fig. 1: Geological map of Kechros area showing the locations of the studied eclogites (Mposkos and Krohe, 2000).

2002). The underlying Kechros Complex underwent also Alpine HP metamorphism, documented by the common occurrence of fresh eclogites and amphibolitized eclogites with Permo-Triassic age of gabbroic protoliths (Liati and Mposkos, 1990; Liati, 2005). Exhumation to shallow crustal levels of the Kechros Complex occurred in Oligocene (Wawrzenitz and Mposkos, 1997; Lips et al., 2000).

In the present work we describe the geochemistry of eclogites, amphibolitized eclogites and dyke amphibolites from the Kechros Complex. Our objective is to investigate the nature of the protoliths, to provide a compilation of whole-rock major and trace element data and to place constraints on the petrogenesis and geodynamic history of the protoliths of the studied rocks.

\section{Geological setting}

In eastern Rhodope, a discrete tectonic contact separates the Kimi Complex from the underlying Kechros Complex (Fig. 1). The Kechros Complex consists of orthogneisses, metamigmatites (containing muscovite metapegmatite lenses, pelitic gneisses, high-alumina metapelites and rare marbles). Within the orthogneisses and metapelites, boudins of eclogites, eclogite amphibolites and amphibolites occur. Large ultramafic bodies are tectonically intercalated.

In the eclogites P-T conditions of $\sim 1.5 \mathrm{GPa}$ at $\sim 550^{\circ} \mathrm{C}$, are estimated by Grt-Omp $\left(\mathrm{Jd}_{55}\right)$. (Thermobarometry; Liati and Mposkos, 1990). In the orthogneisses and metapelites the HP event is documented by the presence of phengites with maximum 3.5 Si atoms per formula unit (a.p.f.u.) and up to $3.42 \mathrm{Si}$ a.p.f.u. respectively (Mposkos, 1989). Decompression was nearly isothermal from the maximum pressure of $1.5 \mathrm{GPa}$ up to $0.4 \mathrm{GPa}$. It is recorded in metapelites by the successive formation of staurolite, chlorite and biotite at the expense of chloritoid and phengite (Mposkos, 1989; Mposkos and Liati, 1993, their figure 11a) implying rapid uplift. 
Orthogneisses and metapegmatites indicate Variscan protolith ages. U-Pb zircon ages from orthogneisses range between 320-299 Ma (Liati, 2005; Cornelius, 2008). Rb-Sr age of magmatic muscovite in a metapegmatite associated with metamigmatites yielded $334 \mathrm{Ma}$ (Mposkos and Wawrzenitz, 1995). U-Pb ages of magmatic zircons in eclogite yielded $245 \mathrm{Ma}$ for the crystallization time of the gabbroic protolith (Liati, 2005). $\mathrm{Rb}-\mathrm{Sr}$ and ${ }^{39} \mathrm{Ar}-{ }^{40} \mathrm{Ar}$ white mica ages from mylonitic orthogneisses range between 41-36 Ma, constraining minimum age for the Alpine HP metamorphism (Wawrzenitz and Mposkos, 1997; Lips et al., 2000).

\section{Petrography}

The selected eclogites and amphibolitized eclogite samples occur in the following three areas: (1) Charakoma, (2) Kovalo and (3) Virsini (Fig. 1).

The eclogites have the mineral assemblage garnet + omphacite $\left(\mathrm{Jd}_{35-55}\right)+$ tremolite + hornblende \pm glaucophane + epidote \pm kyanite + phengite + rutile + quartz and the retrogressed amphibolitized eclogites tremolite + hornblende + albite + chlorite + epidote + quartz \pm phengite \pm paragonite \pm garnet \pm margarite + rutile. Glaucophane is found as inclusions in garnet from the Kovalo eclogite and kyanite from the Charakoma eclogite. Kyanite is associated with omphacite as inclusions in garnet as well as in the rock matrix. Garnet-clinopyroxene geothermometry yielded $550-620^{\circ} \mathrm{C}$ at $1.5 \mathrm{GPa}$ (minimum pressure constrained from jadeite content in omphacite). However, the coexistence of kyanite with omphacite $\left(\mathrm{jd}_{50}\right)$ constrains the minimum pressure at $2.1 \mathrm{GPa}$ at least for the Charakoma eclogite.

\section{Whole-rock major and trace element analysis}

\subsection{Methods}

Major and trace element compositions of 11 representative samples (Table 1), including eclogites and amphibolitized eclogites, were determined by inductively coupled plasma - emission spectroscopy (ICP-ES). For major and trace element analysis, structural water was removed from sample powders by heating at $1000^{\circ} \mathrm{C}$ for 1 hour. Loss on ignition (LOI) was determined from the total weight change. Major and trace element analyses were performed on solutions after $\mathrm{LiBO}_{2}$ fusion and nitric acid digestion of rock powder for ICP-ES analysis and on prepared beads after mixing with Di-Lithium Tetraborate and fusion for XRF analysis. Rare earth element (REE) analyses were determined by inductively coupled plasma-mass spectroscopy (ICP-MS) after $\mathrm{LiBO}_{2}$ fusion and nitric acid digestion. The detection limits for the REE (in ppm) are $<0.5$ for $\mathrm{La}$ and $\mathrm{Ce},<0.02$ for $\mathrm{Pr},<0.4$ for $\mathrm{Nd}$, $<0.1$ for Sm, $<0.05$ for Eu, Gd, Dy, Ho, Er, Tm and Yb, <0.01 for Tb and Lu. The whole-rock analyses were carried out at Acme Analytical laboratories in Canada.

\subsection{Major elements and compatible trace elements}

Based on $\mathrm{Fe}_{2} \mathrm{O}_{3} \mathrm{t}$ and $\mathrm{TiO}_{2}$ contents, two types of eclogites are distinguished: low-Fe-Ti eclogites (LFT) with $\mathrm{Fe}_{2} \mathrm{O}_{3} \mathrm{t}<9.9 \mathrm{wt} \%$ and $\mathrm{TiO}_{2}<0.79 \mathrm{wt} \%$ and high-Fe-Ti eclogites (HFT) with $\mathrm{Fe}_{2} \mathrm{O}_{3} \mathrm{t}>$ $12.3 \mathrm{wt} \%$ and $\mathrm{TiO}_{2}>1.3 \mathrm{wt} \%$.

\section{Low-Fe-Ti eclogites:}

The LFT eclogites have $\mathrm{SiO}_{2}$ contents that range from 51.5 to $52.9 \mathrm{wt} \%, \mathrm{Al}_{2} \mathrm{O}_{3}$ from 14.1 to 15.9 wt $\%, \mathrm{Fe}_{2} \mathrm{O}_{3}$ t from 7.9 to $9.9 \mathrm{wt} \%, \mathrm{CaO}$ from 8.6 to $10.6 \mathrm{wt} \%, \mathrm{TiO}_{2}$ from 0.48 to 0.79 wt $\%$ and $\mathrm{Na}_{2} \mathrm{O}$ content from 1.75 to $3.14 \mathrm{wt} \%$. $\mathrm{Cr}$, Ni and $\mathrm{Co}$ abundances range from 103 to $438 \mathrm{ppm}, 18$ to 185 ppm and 29 to 44 ppm respectively. 
Table 1. Representative major and trace element compositions of Low-Fe-Ti (LFT) and High-Fe-Ti (HFT) eclogites from the high pressure metamorphic Kechros Complex.

\begin{tabular}{|l|c|c|c|c|c|c|c|c|c|c|c|}
\hline Sample & EK-7 & At-13 & At-13B & EK-6B & EK-9 & 93A-9 & 93A-11 & B90-3B & KO2 & KO4 & KO6 \\
\hline Rock & LFT & LFT & LFT & LFT & LFT & HFT & HFT & HFT & HFT & HFT & HFT \\
\hline Major elements $($ wt\%) \\
\hline $\mathrm{SiO}_{2}$ & 52.46 & 52.86 & 51.67 & 51.49 & 52.04 & 44.56 & 43.48 & 44.55 & 45.68 & 44.29 & 46.01 \\
\hline $\mathrm{TiO}_{2}$ & 0.56 & 0.79 & 0.75 & 0.58 & 0.56 & 2.94 & 2.46 & 2.76 & 2.33 & 2.44 & 1.35 \\
\hline $\mathrm{Al}_{2} \mathrm{O}_{3}$ & 14.56 & 15.00 & 14.54 & 14.71 & 15.95 & 13.10 & 12.71 & 13.16 & 11.74 & 12.27 & 15.92 \\
\hline $\mathrm{Fe}_{2} \mathrm{O}_{3} \mathrm{t}$ & 8.39 & 9.90 & 7.90 & 8.76 & 8.19 & 18.70 & 17.90 & 17.95 & 15.50 & 16.57 & 12.27 \\
\hline $\mathrm{MnO}$ & 0.14 & 0.21 & 0.09 & 0.14 & 0.14 & 0.27 & 0.26 & 0.26 & 0.24 & 0.23 & 0.18 \\
\hline $\mathrm{MgO}$ & 10.15 & 6.17 & 7.54 & 10.62 & 8.97 & 6.76 & 8.21 & 7.28 & 8.19 & 9.24 & 8.59 \\
\hline $\mathrm{CaO}$ & 9.00 & 8.73 & 10.57 & 8.88 & 9.03 & 10.87 & 13.27 & 10.87 & 13.28 & 11.70 & 12.32 \\
\hline $\mathrm{Na}_{2} \mathrm{O}$ & 2.07 & 2.23 & 3.14 & 1.75 & 1.80 & 2.53 & 0.99 & 2.50 & 1.18 & 1.02 & 1.72 \\
\hline $\mathrm{K}_{2} \mathrm{O}$ & 1.11 & 1.44 & 1.13 & 0.73 & 1.18 & 0.07 & 0.10 & 0.08 & 0.15 & 0.21 & 0.28 \\
\hline $\mathrm{P}_{2} \mathrm{O}_{5}$ & 0.12 & 0.22 & 0.17 & 0.11 & 0.13 & 0.07 & 0.18 & 0.08 & 0.18 & 0.15 & 0.11 \\
\hline $\mathrm{LOI}$ & 1.00 & 2.10 & 2.10 & 1.49 & 0.95 & 0.10 & 0.10 & 0.10 & 0.44 & 0.91 & 0.96 \\
\hline $\mathrm{Total}^{2}$ & 99.56 & 99.65 & 99.60 & 99.25 & 98.93 & 99.97 & 99.66 & 99.59 & 98.91 & 99.03 & 99.71 \\
\hline $\mathrm{Mg} \#$ & 0.71 & 0.55 & 0.66 & 0.71 & 0.69 & 0.42 & 0.48 & 0.45 & 0.51 & 0.53 & 0.58 \\
\hline
\end{tabular}

\section{Trace elements (ppm)}

\begin{tabular}{|c|c|c|c|c|c|c|c|c|c|c|c|}
\hline $\mathrm{Ba}$ & 183 & 253 & 216 & 144.4 & 252.2 & 8 & 9 & 14 & 43.3 & 85.9 & 31.5 \\
\hline Cs & 2.9 & 7.4 & 1.1 & $<0.1$ & 6.6 & 0.2 & $<0.1$ & 0.7 & 7.5 & 2.3 & $<0.1$ \\
\hline $\mathrm{Pb}$ & 4.5 & 1 & 2.6 & 18.5 & 29.4 & 0.8 & 0.4 & 0.7 & $<0.1$ & $<0.1$ & 4.1 \\
\hline $\mathrm{Rb}$ & 37.5 & 58.1 & 27.7 & 25.3 & 32.3 & 1.5 & 1.4 & 1.6 & 4.3 & 4.4 & 7.6 \\
\hline $\mathrm{Sr}$ & 409.9 & 416.6 & 656.9 & 466.6 & 754.3 & 36.9 & 45.6 & 45.2 & 129.6 & 33.3 & 338.1 \\
\hline $\mathrm{Ta}$ & 0.2 & 0.5 & 0.3 & $<0.1$ & $<0.1$ & 0.3 & 0.3 & 0.4 & $<0.1$ & $<0.1$ & $<0.1$ \\
\hline Th & 2.9 & 4 & 2.7 & 11.7 & 6.3 & $<0.2$ & $<0.2$ & $<0.2$ & 4.9 & $<0.2$ & $<0.2$ \\
\hline $\mathrm{U}$ & 1 & 1.8 & 1.6 & $<0.1$ & $<0.1$ & $<0.1$ & $<0.1$ & $<0.1$ & $<0.1$ & $<0.1$ & $<0.1$ \\
\hline $\mathrm{Nb}$ & 2.4 & 5.1 & 3.9 & $<0.1$ & $<0.1$ & 4.7 & 4.4 & 6.1 & $<0.1$ & $<0.1$ & $<0.1$ \\
\hline $\mathrm{Zr}$ & 54.1 & 91.4 & 69.8 & 30.2 & 45 & 149.5 & 108.5 & 215.5 & 94.9 & 99.5 & 40.2 \\
\hline$Y$ & 14.5 & 21.3 & 17.9 & 15.1 & 16.8 & 61.8 & 51.5 & 74 & 36.9 & 39.1 & 27.1 \\
\hline $\mathrm{Ni}$ & 178 & 59 & 83 & 185.3 & 133.6 & 73 & 68 & 74 & 91 & 171.7 & 108.2 \\
\hline $\mathrm{Cr}$ & 417.38 & 102.63 & 157.37 & 207.4 & 211.9 & 88.95 & 116.32 & 164.21 & 189.9 & 167.2 & 297.4 \\
\hline $\mathrm{La}$ & 10.4 & 16.2 & 13 & 11.4 & 11.5 & 4.9 & 2.9 & 6.4 & 3.40 & 3.12 & 3.2 \\
\hline $\mathrm{Ce}$ & 22.3 & 33.8 & 27.9 & 23.6 & 24.3 & 17.5 & 11.1 & 21.9 & 12.29 & 11.40 & 9.8 \\
\hline $\operatorname{Pr}$ & 2.92 & 4.52 & 3.68 & 3.02 & 2.94 & 3.21 & 2.29 & 3.94 & 2.41 & 2.29 & 1.63 \\
\hline $\mathrm{Nd}$ & 13.1 & 19.3 & 16.2 & 13.7 & 13.4 & 18.1 & 14.9 & 22.8 & 13.41 & 12.95 & 9.2 \\
\hline $\mathrm{Sm}$ & 2.85 & 4.15 & 3.73 & 3.1 & 3 & 6.12 & 4.87 & 7.26 & 4.84 & 4.63 & 3.4 \\
\hline $\mathrm{Eu}$ & 0.8 & 1.05 & 1.16 & 0.96 & 0.86 & 2.09 & 1.74 & 2.3 & 1.97 & 1.66 & 1.3 \\
\hline $\mathrm{Gd}$ & 2.74 & 3.86 & 3.55 & 2.9 & 2.8 & 7.68 & 6.48 & 9.15 & 6.51 & 6.31 & 4.5 \\
\hline $\mathrm{Tb}$ & 0.43 & 0.6 & 0.58 & 0.5 & 0.46 & 1.63 & 1.32 & 1.86 & 1.23 & 1.18 & 0.84 \\
\hline Dy & 2.48 & 3.68 & 3.31 & 2.67 & 2.6 & 10.56 & 8.53 & 12.03 & 8.09 & 7.80 & 5.27 \\
\hline Ho & 0.51 & 0.73 & 0.63 & 0.59 & 0.58 & 2.25 & 1.82 & 2.61 & 1.74 & 1.68 & 1.2 \\
\hline $\mathrm{Er}$ & 1.47 & 2.29 & 1.87 & 1.54 & 1.55 & 6.84 & 5.57 & 8.34 & 5.10 & 4.98 & 3.33 \\
\hline $\mathrm{Tm}$ & 0.22 & 0.32 & 0.24 & 0.23 & 0.23 & 0.99 & 0.8 & 1.17 & 0.75 & 0.74 & 0.52 \\
\hline $\mathrm{Yb}$ & 1.5 & 2.09 & 1.55 & 1.5 & 1.42 & 6.51 & 5.25 & 7.66 & 4.81 & 4.80 & 3.17 \\
\hline $\mathrm{Lu}$ & 0.22 & 0.31 & 0.23 & 0.25 & 0.22 & 0.97 & 0.78 & 1.13 & 0.70 & 0.70 & 0.5 \\
\hline$[\mathrm{Gd} / \mathrm{Yb}] \mathrm{N}$ & 1.51 & 1.53 & 1.89 & 1.60 & 1.63 & 0.98 & 1.02 & 0.99 & 1.12 & 1.09 & 1.17 \\
\hline $\begin{array}{l}\mathrm{La} / \mathrm{Yb}] \mathrm{N} \\
\end{array}$ & 4.97 & 5.56 & 6.02 & 5.45 & 5.81 & 0.54 & 0.40 & 0.60 & 0.51 & 0.47 & 0.72 \\
\hline [Eu/Eu*] & 0.88 & 0.80 & 0.97 & 0.98 & 0.91 & 0.93 & 0.95 & 0.86 & 1.07 & 0.94 & 1.02 \\
\hline
\end{tabular}



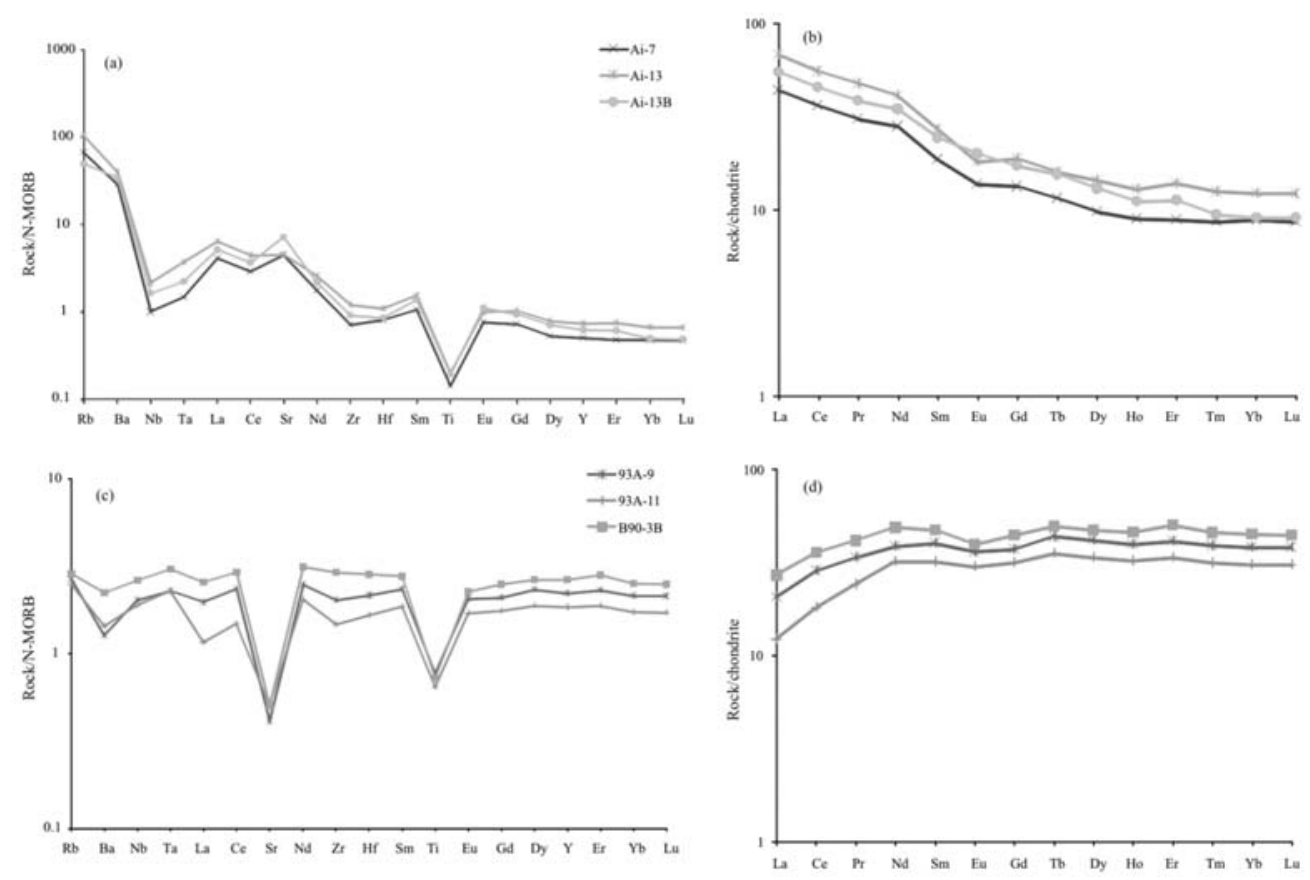

Fig. 2: N-MORB and chondrite-normalized trace-element diagrams for LFT (a,b), and HFT (c,d) eclogites. Normalizing values are from Sun \& McDonough (1989).

\section{High-Fe-Ti eclogites:}

The HFT eclogites have $\mathrm{SiO}_{2}$ contents that range from 43.5 to $46.0 \mathrm{wt} \%, \mathrm{Al}_{2} \mathrm{O}_{3}$ from 11.7 to 15.9 wt $\%, \mathrm{Fe}_{2} \mathrm{O}_{3}$ t from 12.3 to $18.7 \mathrm{wt} \%, \mathrm{CaO}$ from 10.9 to $13.3 \mathrm{wt} \%, \mathrm{TiO}_{2}$ from 1.3 to $2.9 \mathrm{wt} \%$ and $\mathrm{Na}_{2} \mathrm{O}$ content from 1.0 to $2.5 \mathrm{wt} \%$. Cr, Ni and $\mathrm{Co}$ abundances range from 89 to $297 \mathrm{ppm}, 68$ to 172 ppm and 45 to 66 ppm respectively.

\subsection{Incompatible trace elements}

\section{Low-Fe-Ti eclogites:}

N-MORB normalized trace elements patterns (Fig. 2a) are characterized by negative Nb-Ta and Ti anomalies, small positive $\mathrm{Sr}$ anomalies, high LILE (Rb, Ba) abundances and relatively flat high field strength elements (HFSE) from Zr-Lu with the exception of Sm which shows small positive anomalies.

The REE patterns normalized to chondrite (Fig. 2b) are characterized by strong LREE enrichment $\left(\mathrm{La}_{\mathrm{N}} / \mathrm{Yb}_{\mathrm{N}}=4.97-6.02\right)$, HREE depletion $\left(\mathrm{Gd}_{\mathrm{N}} / \mathrm{Yb}_{\mathrm{N}}=1.51-1.89\right)$ and HREE abundance within the range of $8-12 \times$ chondrite.

\section{High-Fe-Ti eclogites:}

N-MORB normalized trace element patterns (Fig. 2c) are characterized by very strong negative $\mathrm{Sr}$ and Ti anomalies, small to moderate LILE enrichment, HREE`s similar to MORB values and absence of $\mathrm{Nb}$ anomalies. 
The REE patterns normalized to chondrite (Fig. 2d) are characterized by LREE depletion $\left(\mathrm{La}_{\mathrm{N}} / \mathrm{Yb}_{\mathrm{N}}=0.40-0.72\right)$, slight negative Eu anomalies $\left(\mathrm{Eu} / \mathrm{Eu}^{*}=0.94-1.07\right)$ and relatively flat MREEHREE patterns. They fall within the range of $13-45 \times$ chondrite for both LREE and HREE.

\section{Discussion}

\subsection{Compositional modification during metamorphism}

Seawater alteration, dehydration during metamorphism and partial melting are the main processes that could affect the composition of the protoliths of the LFT and HFT after their initial formation. Seawater alteration includes two opposite processes; the first is that they gain LILE and alkalis and the second is that they lose $\mathrm{Si}, \mathrm{Mg}$ and $\mathrm{Ca}$ (Jacob et al., 1994).

Dehydration and loss of a melt component during passing from eclogite to amphibolite facies conditions could affect mainly the $\mathrm{SiO}_{2}$ content and in lesser degree the LILE and LREE contents of the bulk-rock composition (Stalder et al., 1998; Foley et al., 2002). This could be done due to transformation of clinopyroxene to amphibole at high water activity. Besides, the more compatible elements (Cr, Ni, HREE) in eclogitic minerals (e.g. clinopyroxene and garnet) are less mobile and remain at the peak P-T conditions (Jacob and Foley, 1999). The HFSE (Nb, Ta, Zr, Hf) and Th have very low mobility in retrograde fluids and retain at the eclogitic primary or accessory minerals (Elliott et al., 1997; Hebert et al., 2009).

The incompatible elements enrichment of LFT eclogites could be attributed to mineral-fluid interaction at high-pressure conditions or even low-T seawater alteration. Low-T seawater alteration is a mechanism that theoretically is present but is difficult to influences all of the samples in a consistent way producing parallel trace element/REE patterns. Though, the Rb, Ba, K enrichments in our eclogitic samples (especially in LFT) is due to the extensive rehydration mechanism which results in the formation of hornblende (Becker et al., 2000). Petrographic data from the LFT eclogites suggest that the retrograde amphibole is in very high modal content indicating extended water fluxes. During the formation of such amphibole, a fluid phase, rich in $\mathrm{Rb}, \mathrm{Ba}$ and $\mathrm{K}$, is consumed in order to complete the reaction, by increasing the LILE contents in the eclogites. Another LILE element such as Cs, is positively and more strongly correlated with $\mathrm{K}$ (diagram not shown) indicating that retrograde fluids could affect its concentration.

In fact, the REE patterns of both LFT and HFT eclogites vary interconsistently probably reflecting primary composition of the protoliths.

In order to check the relative mobilization of various elements, we investigate the role of the theoretical immobile elements. The HFSE`s (Nb, Ta, Zr, Ti) and the REE`s are seem to be relative less mobile during retrogression process.

\subsection{Bivariate $\mathrm{TiO}_{2}-\mathrm{Mg} \#$ vs. Major/trace element plot}

Major and trace element vs. $\mathrm{TiO}_{2}$ plots are shown in Figure 3. They display the following trends with decreasing $\mathrm{TiO}_{2}$ : (1) The HFT eclogites show $\mathrm{CaO}, \mathrm{MgO}$ and $\mathrm{Cr}$ concentrations which more or less continuous negative trend with $\mathrm{TiO}_{2}$ whereas $\mathrm{Fe}_{2} \mathrm{O}_{3}$ t is positively correlated; (2) $\mathrm{SiO}_{2}$ remain nearly constant at decreasing $\mathrm{TiO}_{2}$ content whereas $\mathrm{Na}_{2} \mathrm{O}$ decreasing for $\mathrm{TiO}_{2}>2.4 \mathrm{wt} \%$ and increasing for lower $\mathrm{TiO}_{2}$ contents; (3) $\mathrm{CaO}, \mathrm{MgO}, \mathrm{Fe}_{2} \mathrm{O}_{3}$ t lie above the MORB field whereas $\mathrm{SiO}_{2}$ and $\mathrm{Na}_{2} \mathrm{O}$ fall below the field defined for MORB-type basaltic rocks; $\mathrm{Cr}$ is plotted within the MORB field. In contrast to the HFT eclogites, the LFT ones, display limited range of $\mathrm{TiO}_{2}$ showing (1) steep negative 

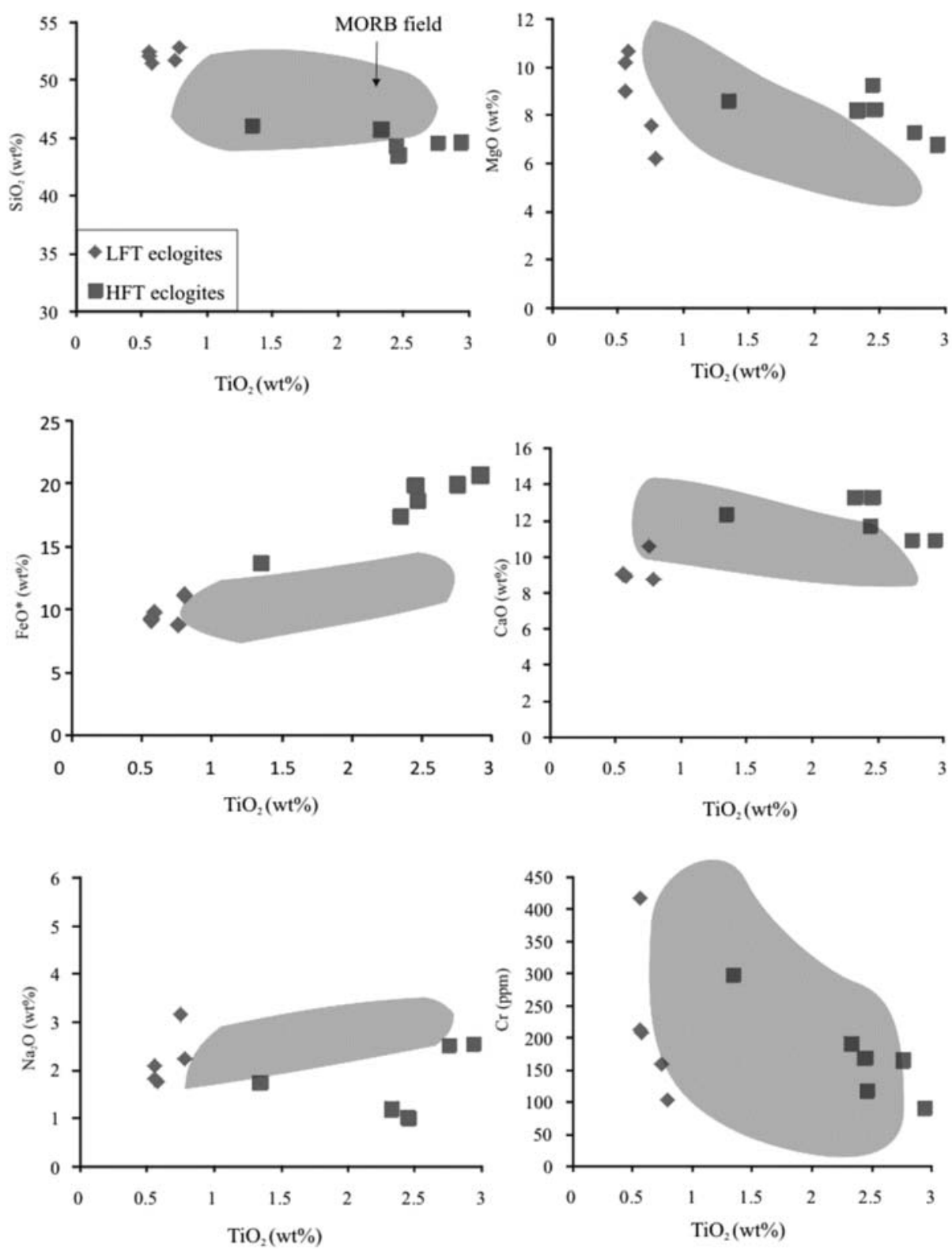

Fig. 3: Selected major and trace elements vs. $\mathrm{TiO}_{2}$ for both LFT and HFT eclogites. Grey field represents MORB values.

trends for $\mathrm{Cr}$ and $\mathrm{MgO}$, whereas the major elements $\mathrm{CaO}, \mathrm{SiO}_{2}, \mathrm{FeO} *$ and $\mathrm{Na}_{2} \mathrm{O}$ contents are more scattered without obviously trends; (2) comparing the values of the LFT eclogites, are generally plotted outside the MORB field.

The evolution of the $\mathrm{Mg}$ - to Fe-rich gabbroic rocks is well established in bivariate plots of selected major and trace elements vs. $\mathrm{Mg \#} \mathrm{(figure} \mathrm{not} \mathrm{shown).} \mathrm{The} \mathrm{compatible} \mathrm{elements} \mathrm{such} \mathrm{as} \mathrm{Cr}$ and $\mathrm{Ni}$ 


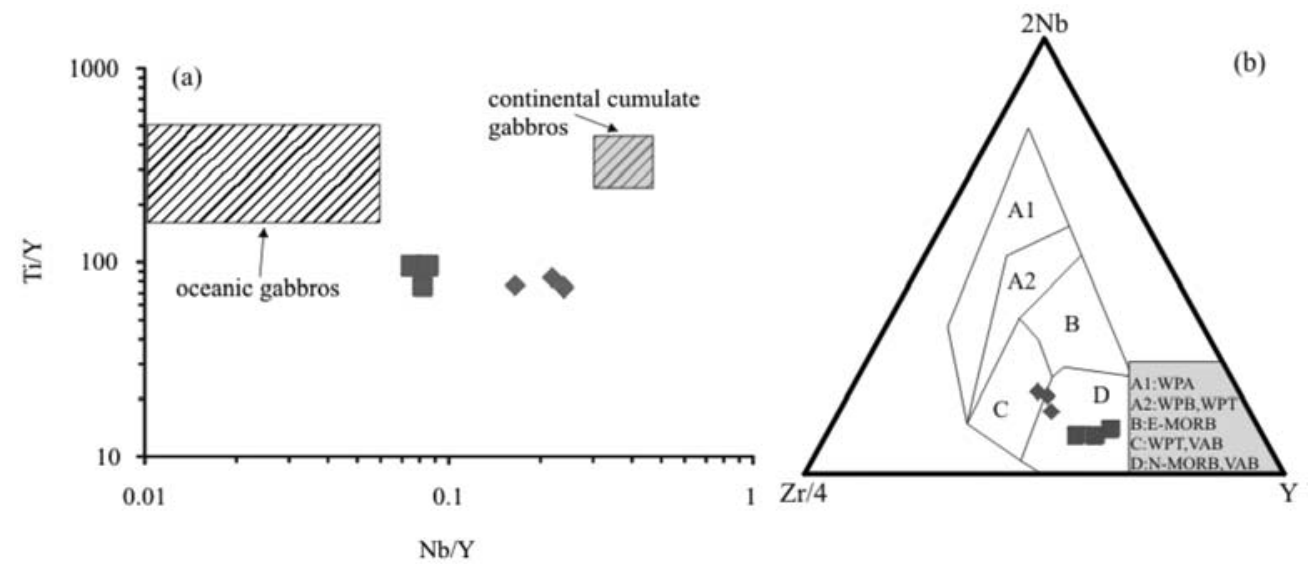

Fig. 4: (a) $\mathrm{Nb} / \mathrm{Y}$ vs. Ti/Y variation diagram comparing LFT and HFT eclogites with continental and oceanic gabbros. (b) Nb-Zr-Y ternary plot showing the contrasting tectonic signatures of LFT and HFT eclogites. Symbols for both LFT and HFT eclogites as in figure 3.

decrease with decreasing Mg\# whereas the elements Zr, P, Ti and Y increase with decreasing Mg\# for both LFT and HFT eclogites respectively. However, the LFT eclogites display higher Mg\# and do not show coherent and continuous fractionation trends for most of the elements compared with HFT eclogites. Within each sampling area of the study region, the eclogites have parallel REE patterns with systematically increasing REE concentration with decreasing Mg\#. The LFT eclogites display LREE-enriched patterns whereas the HFT eclogites generally display LREE-depleted patterns. The above geochemical features suggest that the studied eclogites represent gabbroic rocks having different petrogenetic histories. The gabbroic character of these eclogites is also verified in the LFT eclogite from Charakoma area were relics of the primary gabbro are preserved in the central part of the eclogite body (Liati and Mposkos, 1990).

\section{Tectonic setting}

As already shown in the geochemistry section, the LFT eclogites have rift-related signatures whereas the HFT eclogites have MORB signatures. Such speculations could represented in a Ti/Y-Nb/Y variation diagram (Fig. 4a), in which the two types of eclogites are shown; both types of eclogites share similar Ti/Y values ( 66-84 for LFT and 75-99 for HFT) but significant different $\mathrm{Nb} / \mathrm{Y}$ values (0.170.22 for LFT and $\sim 0.08$ for HFT). The LFT samples are plotted close to the continental cumulate gabbros whereas the HFT close to the oceanic gabbros; however both eclogites are shifted toward lower $\mathrm{Ti} / \mathrm{Y}$ values.

\section{Low-Fe-Ti eclogites}

The LFT eclogites have rift-related enriched-REE patterns. Trace element systematics such as the high $\mathrm{Ce} / \mathrm{Nb}(>6.6)$ and $\mathrm{Th} / \mathrm{Yb}(1.74-7.80)$ ratios span over the $\mathrm{N}-\mathrm{MORB}$ range for the $\mathrm{Ce} / \mathrm{Nb}(\sim 3.2)$ and $\mathrm{Th} / \mathrm{Yb}(\sim 0.04)$. Most of the samples are plotted in the $\mathrm{C}$ field of the ternary diagram $\mathrm{Nb}-\mathrm{Zr}-\mathrm{Y}$ (Fig. 4b) which corresponds to within-plate or volcanic-arc basalts; though indicates the rift-related signatures of the LFT eclogite protolith. The geochemistry of LFT eclogites suggests formation in a rift-related tectonic setting. 


\section{High-Fe-Ti eclogites}

The HFT eclogites have typical MORB-type REE patterns. Currently, trace element geochemistry systematics suggest an $\mathrm{N}-\mathrm{MORB}$ protolith. The $\mathrm{Ce} / \mathrm{Nb}$ ratios range from 2.52 to 3.72 , whereas the $\mathrm{Th} / \mathrm{Yb}$ ratios are lower than 1.02 . The above ratios span over the $\mathrm{N}-\mathrm{MORB}$ range for the $\mathrm{Ce} / \mathrm{Nb}$ $(\sim 3.2)$ and $\mathrm{Th} / \mathrm{Yb}(\sim 0.04)$. All of the samples are plotted within D field of the diagram Nb-Zr-Y, indicating N-MORB signatures for the HFT eclogite protolith (Fig. 4b). Nb and Ti depletion observed in N-MORB-normalized trace element patterns is consistent with fractionation and continuous removal of minor amounts of Ti-bearing phase such as rutile. Besides, all of the analyzed samples show negative $\mathrm{Nb}$ - Ta, $\mathrm{Sr}$ and $\mathrm{Ti}$ anomalies in their N-MORB normalized trace element patterns suggesting that the protolith was oceanic crust, derived from a depleted mantle in a SSZ environment.

\section{Conclusions-Results}

The eclogites from Charakoma, Kovalo and Virsini areas are the metamorphic equivalents of gabbroic rocks in terms of mineral assemblages, major and trace element geochemistry.

Based on the geochemical data presented on this study, the studied eclogites are divided into two groups. The first group (Charakoma locality-LFT eclogites) displays strong LREE enrichment, HREE depletion, low Ti and Fe contents, variable enrichments in LILE (e.g. Rb and Ba), negative $\mathrm{Nb}-\mathrm{Ta}, \mathrm{Zr}$ and $\mathrm{Hf}$ anomalies and positive $\mathrm{Sr}$ anomalies. Their protoliths have been formed in a continental rifting tectonic environment. The second group (Kovalo and Virsini locality-HFT eclogites) show LREE depletion and relative flat MREE-HREE on REE patterns, high Ti and Fe contents, small to moderate LILE enrichment, variable Sr contents, HREE`s similar to MORB values and absence of $\mathrm{Nb}$ anomalies. The protoliths of the HFT eclogites indicate formation by partial melting in an extensional oceanic environment.

\section{Acknowledgments}

I.B. and E.M. were financially supported by the Special Research project "PEBE 2008" funded by National Technical University of Athens.

\section{References}

Bauer, C., Rubatto, D., Krenn, K., Proyer, A. and Hoinkes, G. 2007. A zircon study from the Rhodope metamorphic complex, N-Greece: Time record of a multistage evolution. Lithos, 99, 207-228.

Baziotis, I., Mposkos, E. and Asimow, P.D. 2008. Petrogenesis of ultramafic rocks from the ultrahigh-pressure metamorphic Kimi Complex in Eastern Rhodope (NE Greece). Journal of Petrology, 49, 5, 885-909.

Becker, H., Jochum, K.P. and Carlson, R.W. 2000. Trace element fractionation during dehydration of eclogites from high-pressure terranes and the implications for element fluxes in subduction zones. Chemical Geology, 163, 65-99.

Burg, J.P., Ricou, L.E., Ivanov, Z., Godfriaux, I., Dimov, D. and Klain, L. 1996. Syn-metamorphic nappe complex in the Rhodope Massif: structure and kinematics. Terra Nova, 8, 6-15.

Cornelius, N.K., 2008. UHP metamorphic rocks of the Eastern Rhodope Massif, NE Greece: new constraints from petrology, geochemistry and zircon ages. PhD Thesis, Johannes-Gutenberg Universität, Mainz.

Elliott, T., Plank, T., Zindler, A., White, W. and Bourdon, B. 1997. Element transport from slab to volcanic front at the Mariana arc. Journal of Geophysical Research, 102 (B7), 14991-15019.

Ernst,W.G. and Liou, J.G., 1995. Contrasting plate-tectonic styles of the Qinling-Dabie-Sulu and Franciscan metamorphics. Geology 23, 353-356. 
Foley, S.F., Tiepolo, M. and Vannucci, R. 2002. Growth of continental crust controlled by melting of amphibolite, not eclogite. Nature, 417, 837-840.

Hebert, L.B., Asimow, P.D. and Antoshechkina, P. 2009. Fluid source-based modeling of melt initiation within the subduction zone mantle wedge: Implications for geochemical trends in arc lavas. Chemical Geology, 266, 306-319.Jacob, D.E. and Foley, S.F. 1999. Evidence for Archean ocean crust with low high field strength element signature from diamondiferous eclogite xenoliths. Lithos, 48, 317-336.

Jacob, D.E., Jagoutz, E., Lowry, D., Mattey, D. and Kudrjavtseva, G. 1994. Diamondiferous eclogites from Siberia: remnants of Archean oceanic crust. Geochimica et Cosmochimica Acta, 58, 5191-5207.

Jacob, D.E. and Foley, S.F., 1999. Evidence for Archean ocean crust with low high field strength element signature from diamondiferous eclogite xenoliths. Lithos, 48, 317-336.

Krohe,A. and Mposkos, E., 2002. Multiple generations of extensional detachments in the Rhodope Mountains (N.Greece): evidence of episodic exhumation of high-P rocks. In: Blundell, D.J., Neubauer, G. and Von Quant, A. (eds.): The timing and location of major ore deposits in an evolving orogen. Geological Society of London, Special Publication, 204, 151-178.

Liati, A., 2005. Identification of repeated Alpine (ultra) high-pressure metamorphic events by U-pb SHRIMP geochronology and REE geochemistry of zircon: the Rhodope zone of Northern Greece, Contributions to Mineralogy and Petrology 150, 608-630.

Liati, A. and Mposkos, E., 1990. Evolution of the eclogites in the Rhodope Zone of northern Greece, Lithos, 25, 89-99.

Lips, A.L.W., White, S.H. and Wijbrans, J.R. 2000. Middle-Late Alpine thermotectonic evolution of the southern Rhodope Massif, Greece. Geodinamica Acta, 13, 281-292.

Martin, R.F., 1998. Symbols of the rock-forming minerals. The Nomenclature of minerals: A compilation of IMA reports. IMA' 98 Toronto, 148-149.

Mposkos, E., 1989. High-pressure metamorphism in gneisses and pelitic schists in the Eat Rhodope Zone (N. Greece). Mineralogy and Petrology, 41, 25-39.

Mposkos, E. and Krohe, A., 2000. Petrological and structural evolution of continental high pressure (HP) metamorphic rocks in the Alpine Rhodope domain (N.Greece). Proceedings of the 3rd International Conference on the Geology of the Eastern Mediterranean, 221-232.

Mposkos, E. and Kostopoulos, D., 2001. Diamond, former coesite and supersilicic garnet in metasedimentary rocks from the Greek Rhodope: a new ultrahigh-pressure metamorphic province established. Earth and Planetary Science Letters, 192, 497-506.

Mposkos, E. and Liati, A., 1993. Metamorphic evolution of metapelites in the high-pressure terrane oft he Rhodope zone, Northern Greece. Canadian Mineralogist, 31, 401-424.

Mposkos, E. and Wawrzenitz, N., 1995. Metapegmatites and pegmatites bracketing the time of HP-metamorphism in polymetamorphic rocks of the E-Rhodope: Petrological and geochronological constraints. Geological Society of Greece, Special Publication 2(4), 602-608.

Stalder, R., Foley, S.F., Brey, G.P. and Horn, I. 1998. Mineral-aqueous fluid partitioning of trace elements at $900-1200^{\circ} \mathrm{C}$ and 3.0-5.7 GPa: new experimental data for garnet, clinopyroxene, and rutile, and implications for mantle metasomatism. Geochimica et Cosmochimica Acta, 62, 1781-1801.

Sun, S.S. and McDonough, W.F., 1989. Chemical and isotopic systematics of oceanic basalts: implications for mantle composition and process. In: Saunders, A.D. \& Norry, J.M. (eds) Magmatism in Ocean Basins. Geological Society of London, Special Publications 42, 313-345.

Wawrzenitz, N. and Mposkos, E., 1997. First evidence for lower Cretaceous HP / HT-metamorphism in the Eastern Rhodope, North Aegean Region, North-East Greece. European Journal of Mineralogy, 9, 659-664. 